\title{
Evaluation of a semi-quantitative method for rapid screening of plant phenolic content
}

\author{
Anthony B. Anderson (') \\ Theodore V. St. John $\left.{ }^{2}\right)$
}

\begin{abstract}
A rapid method for screening phenolic content in leaves is described and evaluated. The method is based on a treated paper strip that is squeezed around a leaf with pliars. Weaknesses of the method are some subjectivity, lack of precision, and apparent insensitivity to phenolics present as glycosides. Strengths include its speed and independence of laboratory facilities. Immediate testing of leaves following detachment appears to be essential. The crude extraction in the field compares favorably with a more conventional extraction technique. The method is recommended for use in preliminary screening of plant material when a large number of species must te examined within a short time and when laboratory facilities are not available at the field site.
\end{abstract}

\section{INTRODUCTION}

Plant phenolics constitute a large and varied chemical class that includes pigments, metabolic compounds, and so-called secondary compounds. The last group is of special interest to ecologists and contains compounds that have been implicated as protective agents against herbivores and pathogens (cf. Levin, 1971), allelopathic substances (cf. Rice, 1974), and decomposition inhibitors (cf. Handiley, 1961; Benoit \& Starkey, 1968a, 1968b). The chemistry and functions of phenolics have been discussed at length (e.g., Levin, 1971; Walker, 1975; Swain, 1977).

The method chosen for phenolic determination depends on one's objectives. For chemical taxonomy, chromatographic techniques are often appropriate (Hathway, 1969). In the tanning industry, gelatin and hide powder precipitation are the basis of a complex and empirical determination (White, 1958). Ecologists may be more interested in a measure of total tannin content. For this purpose colorime- tric determinations of a water extract has often been employed (Allen et al., 1974). Feeny \& Bostock (1968) used a more sophisticated gravimetric procedure on an acetone-water extraction.

Burns (1968) reviewed phenolic methods for use in assessing forage quality. Among his suggestions was a screening test based on paper strips impregnated with ferric, ammonium citrate. Each strip is squeezed around a leaf to produce a dark spot proportional in intensity to the phenolic concentration in the leaf. This method could have considerable appeal to tropical ecologists. It is independent of laboratory facilities, easily used in remote sites, and sufficiently rapid to allow evaluation of a large number of samples within a short time. Probably no alternative would permit examination of the great number of species characteristic of some tropical environments. For these reasons we undertook a critical evaluation of the reproducibility and utility of Burns's method.

\section{METHODS}

\section{FIELD SITES}

Leaf samples were obtained from two distinctive vegetation types in the vicinity of Manaus, Amazonas State, Brazil: (1) Amazon caatinga, a scrub vegetation on white sand (entisol) in the Biological Reserve of INPA/ SUFRMA, $61 \mathrm{~km}$ north of Manaus on highway BR-174 ( $\mathrm{km} \mathrm{45)}$; and (2) primary forest on heavy clay (oxisol) on the grounds of EMBRAPA, 31 $\mathrm{km}$ east of Manaus on highway AM-010. Phytosociological data are available in Anderson et al. (1975) for the white sand site and in Prance et al. (1976) for the clay site.

(1) - Department of Botany, University of Florida. Gainesville, Florida 32611.

(2) - Natural Resource Ecology Laboratory, Colorado State University. Fort Collins, Colorado 80523. 


\section{LEAF COLLECTION}

Leaf samples were obtained from a total of 210 species. Foliage was taken with a shotgun or by climbing the trees except at the white sand site, where they could be picked off the shrubs or low trees at ground level. Ten leaves per species were collected for testing, usually from 2-3 separate branches. Leaves were usually obtained from the lower portion or center of the crowns. To test for variability within individual plants, a subsample of six leaves from various portions of the crown was obtained from one individual of each of ten white sand species. Whenever possible, sampling was limited to mature leaves believed to be of the current year's crop. All samples were collected during the rainy season, from January to April, 1977.

Because of difficulties in collecting from tall trees on the oxisol site, leaf samples in both sites were taken from a single individual of each species. To test for variability among individual plants of a given species, subsamples were obtained from five individuals of ten white sand species.

\section{FIELD SCREENING METHOD}

The method for screening leaf phenolics was adapted from Burns (1968). A strip of filter paper previously impregnated with $0.5 \%$ (wt./vol.) ferric ammonium citrate was folded around the base of each leaf near the petiole (but not across the midrib) and squeezed with pliars. A concentration of $0.5 \%$ was used instead of the $2 \%$ recommended by Burns. A preliminary survey of 32 species showed that intensity of test spots is virtually independent of solution concentration over the range tested, and the lower concentration produced less discoloration of the test paper. We elimınated Burns's use of a second strip of untreated filter paper inside the test strip. The second strip was found to be impractical because many of the leaves were sclerophyllous and contained insufficient fluids to dampen the treated strip. Testing was usually carried ou tin the field immediately after obtaining the leaves. The effect of a 5-hour lag time was determined in a subsample of six white sand species.
Leaf phenolics react with ferric on the test strips, producing a stained spot that varies in intensity. On the basis of spot intensity. leaves can be assigned ot categories of leaf phenolic concentration. Although Burns recommended the use of ten categories, we were able to clearly distinguish only six.

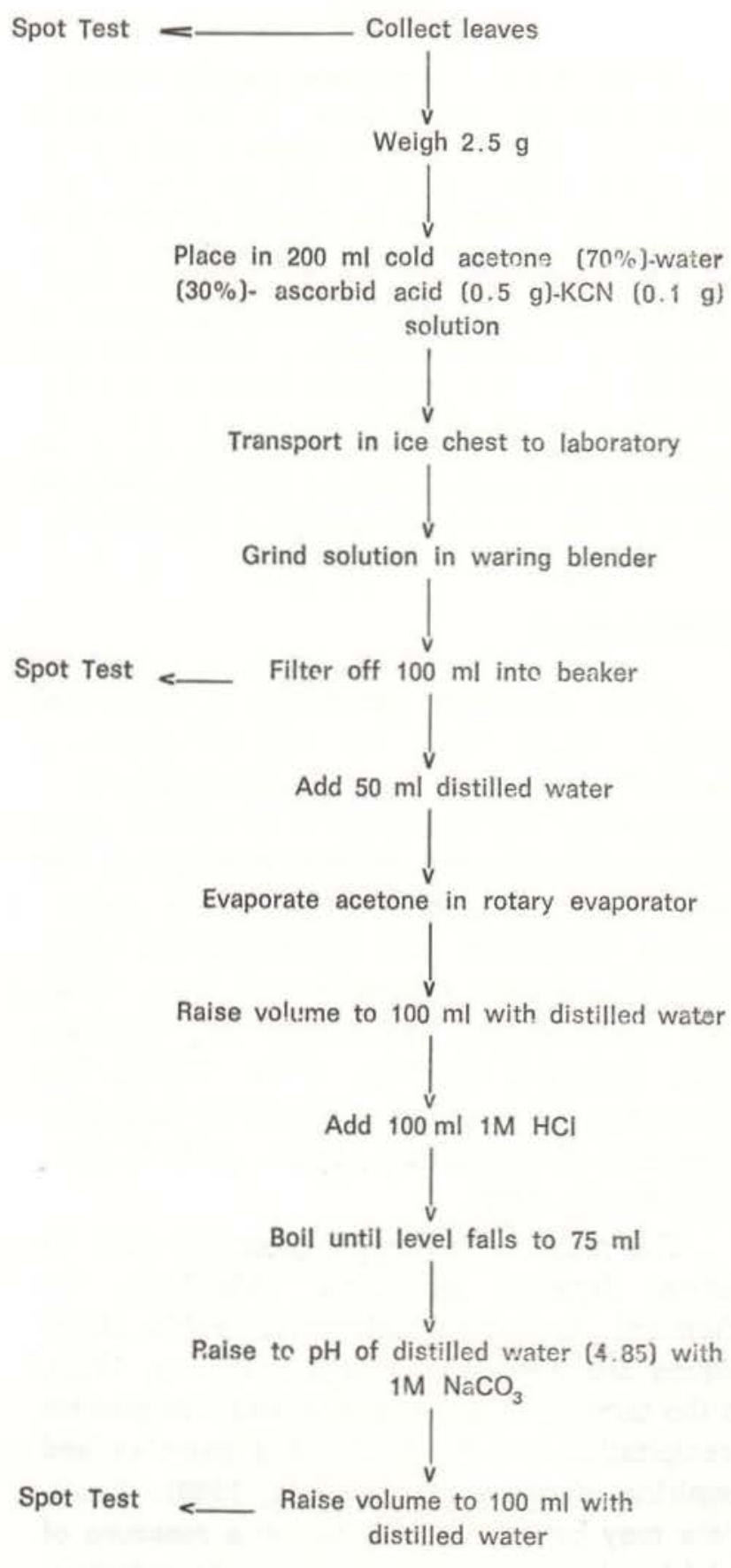

Fig. 1 - Flow chart of extraction procedure used for comparison with phenolic screening method. 


\section{COMPARISON WITH STANDARDS}

The six categories of spot intensities produced by our samples were compared with three types of standards developed by dipping test strips into known concentrations of tannic acid, quebracho tannin, and wattle tannin. To test the permanence of the spot, the original standards were compared one year later with test strips (taken from the same batch as the original standards) dipped into newly prepared tannic acid solutions.

COMPARISON WITH SOLVENT EXTRACTION, ACID HYDROLYSIS, AND FOLIN-DENNIS TEST

The phenolic screening test was carried out on fresh leaves of eleven white sand species and compared with the same test following (a) extraction in an acetone-water solution and (b) acid hydrolysis (Fig. 1). Finally, the phenolic screening method was carried out on fifteen white sand species; separate leaf samples of these species were oven dried and analyzed by the Folin-Dennis method.

\section{RESULTS}

\section{SURVEY OF TWO VEGETATION TYPES}

Results of the screening of leaves in the two vegetation types are presented in the Appendix.

\section{VARIABILITY WITHIN PLANTS}

Leaves of ten species were used to determine whether samples from different portions of the same plant differ detectably. In two of these species, one of the six tests differed from the others by a singie category; the other eight species had no variation within the plant.

\section{VARIABILITY AMONG PLANTS OF A GIVEN SPECIES}

Leaves of five individuals in each of ten species were examined to determine whether detectable variability exists among plants of a given species. One individual of one species differed by a single category from the other four individuals. In all other species, every individual tested was in the same category.

\section{CHANGES IN SPOT INTENSITY AFTER LEAF COLLECTION}

Leaves of six species were tested for changes in phenolic content in the first five hours after detachment from the plant. Four of these did not change and two decreased by one category. One possible mechanism that could account for the decrease is an incorporation of leaf phenolics into glycosides, which may not be detectable by this method (see below). Alternatively, some phenolics may combine with proteins in the cytoplasm. Changes in storage were noted by Bate-Smith and Harborne (1971). The implications of this finding are serious, as leaves are often dried and stored before determination of phenolic content.

CHANGES IN SPOT INTENSITY DURING STORAGE OF TEST PAPERS

Burns (1968) reported that test spots constitute a permanent record. We apparently confirmed this with tannic acid standards. Those stored for a year were not visibly different from freshly prepared standards. However, a 1980 re-examination of test strips made during the 1977 survey revealed that numerous species had darkened by one to three categories of classification. In no case did an initially dark spot lighten. This change could produce considerable error if classification of spots is delayed.

\section{STANDARDS}

Three types of standards were compared with our categories of spot intensity: Quebracho, wattle, and tannil acid. The quebracho and wattle tannis were less soluble in water than tannic acid, and we were unable to dissolve enough of either to match the intensity of category six. 
COMPARISON WITH SOLVENT EXTRACTION

The spot intensities that resulted from dipping test papers into the acetone-water extract were compared in an ordinal sense with the same series of eleven species tested in the field. The sequences of species were identical. This indicates that similar phenolic fractions are detected when testing fresh leaves in the field and when testing after extraction.

\section{COMPARISON AFTER ACID HYDROLYSIS}

In the test for effects of acid hydrolysis, three of the eleven species showed increases in relative spot intensity after acid hydrolysis. The increases probably indicate that the aglycones liberated by acid are more reactive in this test than the glycosides of the original extract.

\section{COMPARISON WITH FOLIN-DENNIS METHOD}

Finally, oven-dried samples of fifteen species were analyzed by the Folin-Dennis method. Again, we could not compare the two methods directly, but we could rank the two sets of values and compare the sequences. There was no apparent relationship between the two sequences. The difference may result from different sensitivities of the methods. A second source of error may be changes in detectable phenolic content following detachment, drying, and storage of leaves. The large shortterm changes reported above lead us to suspect that the latter effect is the primary source of error.

\section{Discussion}

The phenolic screening method described in this paper has several weaknesses. Among these is the subjectivity involved in categorizing spot intensity. Although the spot was usually a shade of gray, many leaves produced reddish or brown spots. The color had to be disregarded and only the intensity considered in classifying the spots. With practice, the two authors found good agreement when evaluating spots independently. A second weakness of the phenolic screening method is lack of precision: phenolic level is nominal rather than quantitative. Third, the method appears to be insensitive to phenolics present as glycosides. The lack of a solvent extraction does not appear to constitute a weakness, as we obtained similar results with an extraction.

The strengths of the phenolic screening method are its speed and ease of application. These attributes make it ideal for: (a) analysis of large sample sizes in a short time or (b) preliminary screening of samples before using more quantitative or specific methods. One of the greatest advantages of this method may be its immediate application following leaf detachment, before potential alteration of phenolic compounds.

In conclusion, we offer the following suggestions for use of the phenolic screening method:

(1) A single batch of test strips larger than the expected sample size should be prepared. We found variable results when using batches prepared on different occasions.

(2) Standards should be prepared at the outset, with a range of tannic acid concentrations. Spot categories should then be distinguished and assigned a relative value.

(3) The subjective element in evaluating spot intensities may be reduced by having a single person assign categories. This person should evaluate a preliminary sample to become accustomed to classifying test strips.

(4) Several (ca. ten) replicates of each sample should be obtained, and assignment to categories should be based on the most common spot intensity.

(5) Before evaluation, the test strips should be allowed to dry. Evaluation should be made on the same day, and test strips should not be regarded as permanent.

(6) Depending on objectives, collection procedures should be standardized so as to minimize sampling variabliity within leaf, within plant, between plants, and/or between seasons. 
APPENDIX - Relative phenolic content of 211 central Amazonian native species. Species wi hout an asterisk were collected on the oxisol site; species with one asterisk were collected on the with sand site; species with two asterisks were collected on both sites. Phenolic content was evaluated on a scale of 1 to 6 , with 1 having the lowest content. In cases where two values appear, the first refers to the white sand site and the second to the oxisol site.

\section{Species}

Phenolic content

\section{ANNONACEAE}

Anaxagorea phaeocarpa Mart. 4

Annona nitida Mart. ${ }^{*} 3$

A. $\mathrm{sp}$.

Bocageopsis cf. matogrossensis (R.E. Fr.) R.E. Fr.

B. multiflora (Mart.) R.E. Fr.

Duguetia caudata R.E. Fr.

Guatteria olivacea R.E. Fr.

Unonopsis cf. duckei R.E. Fr.

U. stipitata Diels.

\section{APOCYNACEAE}

Ambelania duckei Mgf.

Aspidosperma album (Vahl.) Benoist

Geissospermum argenteum R.E. Woodson in A.C. Smith

Mandevilla krukovii Woodson *

Tabernaemontana cf. disticha A. DC.

T. rupicola Benth. ${ }^{*}$

\section{BOMBACACEAE}

Bombacopsis nervosa (Uitt.) A. Robyns 2

Scleronema micranthum Ducke

\section{BURSERACEAE}

Protium apiculatum Swart.

P. heptaphyllum (Aubl.) March *

P. cf. insigne Engl.

P. paraense Cuatr.

P. opacum Swart.

P. pedicellatum Swart.

P. sp.

sp.

Tetragastris panamensis (Engl.) 0 . Kuntze

T. sp.

CARYOCARACEAE

Caryocar pallidum A.C. Smith

\section{CHRYSOBALANACEAE}

Couepia canomensis (Mart.)) Benth. ex Hook. $f$.

C. obovata Ducke

C. $\mathrm{sp}$.

Hiltella bicornis Mart. \& Zucc.
Species

Phenolic content

H. racemosa Lam.
H. sp."
Licania caudata Prance
L. heteromorpha Benth.
L. hypoleuca Benth.
L. longistyla Fritsch
L. micrantha Miq.
L. octandra (Hoffmgg. ex R.S.) Kuntze
L. pallida Spruce ex Sagot
Parinari excelsa Sabine
COMBRETACEAE
Buchenavia sp.

COMPOSITAE

Mikania roraimensis Robinson ${ }^{*} 5$

Vernonia grisea Baker * 3

DICHAPETALACEAE

Tapura amazonica Poepp. \& Endl. 4

DILLENIACEAE

Doliocarpus spraguei Cheesm.* 2

DUCKEODENDRACEAE

Duckeodendron cestroides Kuhlm. 3

ELAEOCARPACEAE

Sloanea floribunda Spruce ex Benth. 5

S. guianensis (Aubl.) Benth. 6

S. laurifolia Benth. 4

ERYTHROXYLACEAE

Erythroxylum campinense Amaral Jr. ${ }^{\bullet} \quad 5$

EUPHORBIACEAE

Conceveiba guianensis Aubl. 5

Croton sp. 1

Mabea occidentalis Benth. ${ }^{*} 3$

Pausandra cf. macropetala Ducke * 4

Pera schomburgkiana Muell. Arg. "* 5

Pogonophora schomburgkiana Miers ex Benth.

FLACOURTIACEAE

Casearia cf. aculeata Jacq. $\quad 4$

C. silvestris Eichl. 3

Laetia procera Eichl. 3

GESNERIACEAE

Codonanthe sp. ${ }^{*} \quad 1$

GNETACEAE

Gnetum paniculatum Spruce ${ }^{*} \quad 3$

GUTTIFERAE

Clusia columnaris Engl. • 2

C. sp. 1

Tovomita sp. 2

Sp. 3

HUMIRIACEAE

Endopleura uchi (Huber) Cautr. 5

Humiria balsamifera St. Hil. "* 3

Saccoglottis ceratocarpa Ducke 5

S. matogrossensis Malme 4 


\begin{tabular}{ll}
\hline Species & Phenolic content \\
\hline
\end{tabular}

\section{LAURACEAE}

Aniba duckei Kosterm.

A. cf. guianensis Aubl.

Licaria aurea (Hub.) Kost.

L. aritu Ducke

L. sp.

Nectandra rubra (Mez) C. Alber

N. sp. *

Ocotea cf. neesiana (Miq.) Kost. Sp.

\section{LECYTHIDACEAE}

Corythophora alta R. Knuth

C. rimosa $\mathrm{W}$. Rodrigues

Couratari spp.

Eschweilera amara (Aubl.) $\mathrm{Ndz}$.

E. fracta R. Knuth

E. odora (Poepp.) Miers

E. polyantha A.C. Smith

E. sp. 1

E. sp. 2

E. sp. 3

E. sp. 4

E. sp. 5

E. sp, 6

Holopyxidium jaranum (Hub.) Ducke

H. latifolium (A.C. Smith) Knuth

H. sp. 1

H. sp. 2

\section{LEGUMINOSAE:CAESALPINIOIDEAE}

Aldina heterophylla Spr. ex Benth. * 2 Eperua bijuga Ducke 2

Macrolobium arenarium Ducke * 2

M. sp.

Peltogyne paniculata Benth.

Swartzia cf. alterna Benth.

S. corrugata Benth.

S. recurva Poeppig *

S. panacoco (Aubl.) Cowan

S. reticulata Ducke

S. $\mathrm{sp}$.

\section{LEGUMINOSAE:MIMOSOIDEAE}

Inga cf. bullatorugosa Ducke

I. glomeriflora Ducke

I. longiflora Spruce

I. cf. rubiginosa DC.

I. sp.

Piptadenia sp.

Pithecolobium racemosum Ducke

Stryphnodendron racemiferum W. Rodr.

LEGUMINOSAE:PAPILIONOIDAE

Andira unifoliata Ducke

Dalbergia cf. atropurpurea Ducke

Dipteryx odorata (Aubl.) Willd.

Ormosia costulata (Miq.) Kleinh. ${ }^{*}$
Species

Phenolic content

\section{LEGUMINOSAE}

Sp.

LORANTHACEAE

Phthirusa micrantha Eichl. ${ }^{*} \quad 6$

P. rufa (Mart.) Eichl. * 6

MALPHIGIACEAE

Heteropterys nervosa Adr. Juss. • 1

MELASTOMATACEAE

Miconia cf. elaeagnoides Cogn. 4

M. lepidota DC. ${ }^{*}$

M. sp. $\quad 4$

Mouriria lunatantha Morley 5

M. nervosa Pilg. * 5

M. torquata Morley 5

M. sp.

Sandemania hoehnii (Cogn.) Wurdack *

MELIACEAE

Guarea duckei C. DC. 1

G. sp. 3

Trichilia micrantha Benth. 3

T. sp. 5

MONIMIACEAE

Siparuna decipiens A. DC. 3

S. sp. 3

MORACEAE

Brosimum parinaroides Ducke 3

B. utile (H.B.K.) Pittier 3

B. $\mathrm{sp}$. 3

Ficus sp. 4

Helianthostylus sprucei Baillon 1

Helicostylis tomentosa (P. \& E.) Rusby 2

H. $\mathrm{sp}$. 2

Maquira calophylla (P. \& E.) Berg. 3 Naucleopsis caloneura (Hub.) Ducke 4 Sorocea sp.

Sp.

Trimatococcus amazonicus P. \& E.

\section{MYRISTICACEAE}

Iryanthera laevis Markgraf 3

Virola calophylla Warb. 4

v. rufula Warb. 4

MYRSINACEAE

Cybianthus spicatus (H.B.K.) Agostini * 3

MYRTACEAE

Calyptranthes sp.

E. egensis DC.

E. patrisii Vahl. ${ }^{*}$

Marliera sp. $\quad 5$

Myrcia citrifolia (Aubl.) Urb. 5

M. servata McVaugh * 3 


\begin{tabular}{ll}
\hline Species & Phenolic content \\
\hline
\end{tabular}

\section{NYCTAGINACEAE}

Neea cf. altissima P. \& E.

N. sp.

\section{OCHNACEAE}

Ouratea discophora Ducke

O. spruceana Engl.*

\section{OLACACEAE}

Heisteria sp.

Minquartia guianensis Aubl.

PALMAE

Oenocarpus bacaba Mart.

o. minor Mart.

\section{PASSIFLORIACEAE}

Passiflcra faroana Harms

QUIINIACEAE

Quiinia pteridophylla (Radlk.) Pires

\section{RUBIACEAE}

Alibertia $s p$.

Borreria capitata (R. \& P.) DC. ${ }^{*}$

Chimarrhis barbara (Ducke) Brem.

Duroia macrophylla Hub.

D. $\mathrm{sp}$.

Pagamea duckei Standl. ${ }^{\bullet}$

Palicourea corymbifera Standl.

P. nitidella (M. Arg.) Standl. •

Psychotria barbiflora DC.

P. cf. lupulina Benth.

\section{SAPINDACEAE}

Matayba adenanthera Radlk.

M. opaca Radlk.

Talisia cerasina (Benth.) Radlk. *

T. $\mathrm{sp}$.

\section{SAPOTACEAE}

Ecclinusa bacuri Aubr. \& Pellegr.

Eremoluma sagotiana (Baill.) Aubr.

E. williamii Aubr. \& Pellegr.

Glycoxylon inophy.lum (Mart. ex Miq.)

Ducke *

Manilkara amazonica (Hub.) Standl.*

Myrtiluma eugenifolia Baill. (Pierre)

Pouteria caimito (Ruiz \& Pav.) Dadlk.

P. cf. guianensis Aubl.

P. sp.

Prieurella sp.

Richardella cladantha (Sandw.) Baehni

R. cf. macrophyila (Lam.) Aubr.

Sp.

Species

Phenolic content

\section{SIMARUBACEAE}

Simaba cuspidata Spruce ex Engler *. 4

STERCULIACEAE

Theobroma subincana Mart.

3

VIOLACEAE

Papayrola cf. guianensis Aubl. 3

Sp.

2

\section{VOCHYSIACEAE}

Erisma bicolor Ducke 5

E. fuscum Ducke 5

E. sp. 5

Qualea albiflora Warm. 4

Q. paraensis Ducke 5

Q. retusa Spr. ex. Warm. ${ }^{*} 6$

Q. sp.

Vochysia vismiefolia Spruce ex Warm. 4

\section{ACKNOWIEDGMENTS}

Mr. James Van May for providing commercial quebracho and wattle tannin preparations for use as a standard.

Ms. Sandra Knapp and Dr. Philip W. Rundel for determining tannin concentration by the Folin-Dennis method on fifteen species.

Field work was supported in part by a grant from the Brazilian National Research Council to Dr. Paulo de Tarso Alvim. Preparation of the manuscript was supported by U.S. National Science Foundation Grant DEB 78-11201.

\section{Resumo}

Este trabalho descreve um método rápido de avalaiçāo de conteúdo de fenois em folhas de plantas. Esse método baseia-se no esmagamento de parte do limbo em contacto com um papel tratado. A velocidade e a independência da necessidade de laboratório sāo os pontos altos do método. Os pontos baixos são a falta de precisão, a subjetividade da avaliação e a apar sensibilidade à fenois na forma de glicosídeos. Parece ser essencial que o teste seja feito imediatamente após coIher a folha. A extração pelo método grosseiro, no campo, é comparável às técnicas convencionais de extração. O método é recomendado para uso no "screening" de material de planta quando um grande número de espé. cies deve ser examinado em pequeno espaço de tempo e quando não existem facilidades de laboratórios nas proximidades. 


\section{REFERENCES}

ALLEN, S.E.; GRIMSHAW, H.M.; PARKINSON, J.A. \& QUARMBY, C.

1974 - Chemical analysis of ecological materials. John Wiley \& Sons, New York.

ANDERSON, A.B.; PRANCE, G.T. \&

ALBUQUEROUE, B.W.P.

1975 - A vegetação lenhosa da campina da Reserva Biológica INPA-SUFRAMA. Acta Amazonica, 5: 225-246.

BATE-SMITH, E.C. \& HARBORNE, J.B.

1971 - Differences in flavonoid content between fresh and herbarium leaf tissue in Dillenia. Phytochemistry, 10: 1055-1058.

BENOIT, R.E. \& STARKEY, R.L.

1968a - Enzyme inactivation as a factor in the inhibition of decomposition of organic matter by tannins. Soil Sci., 105: 203-208.

1968b- Inhibition of cellulose and some other carbohydrates by tannin. Soil Sci., 105: 291-296.

BURNS, R.E.

1968 - Mehods of tannin analysis for forage crop evaluation. Georgia Agric. Exp. Sta. Tech. Bull., N.S. 32 ,

FEENY, P.P. \& BOSTOCK, H.

1968 - Seasonal changes in the tannin content of oak leaves. Phytochemistry, 7: 871-880.

HANDLEY, W.R.C.

1961 - Further evidence for the importance of residual leaf protein complexes in litter de- composition and the supply of nitrogen for plant growt. Plant and Soil, 15 (1): 37-73.

HATHWAY, D.E.

1969 - Plant phenols and tannins. In: I. Smith (ed.) - Chromatographic and Electrophoretic Te. chniques. v.1. Chromatography. William Heinemann, Bath. p. 390-436.

LEVIN, D.A.

1971 - Plant phenolics: An ecological perspective. Am. Nat., 105: 157-181.

PRANCE, G.T.; RODRIGUES, W.A. \& DA SILVA, M.F.

1976 - Inventário florestal de um hectare de mata de terra firme $\mathrm{Km} 30$ da Estrada ManausItacoatiara. Acta Amazonica, 6: 9-35.

RICE, E.L.

1979 - Allelopathy. Academic Press, New York. SWAIN, T.

1977 - Secondary compounds as protective agents. Ann. Rev. Plant. Physiol., 28: 479-501.

WALKER, J.R.L.

1975 - The biology of plant phenolics. The Institute of Biology's (Studies in Biology, 54) Edward Arnold, Ltd., London.

WHITE, T.

1958 - Chemistry of the vegetable tannins. In: F. O'Flaherty, W.T. Roddy, and R.M. Lollar eds. The Chemistry and Technology of Leather v.2. Reinhold Publ. Co., New York. p. 98-160.

(Aceito para publicação em 11/01/81) 